8. Rekomendacii shchodo polipshennia ekologichnogo stanu pryberezhnykh terytoriy dniprovskykh vodoskhovyshch [Recommendations for improving the ecological condition of the coastal areas of the Dnieper reservoirs] // Dubnyak S.A., Sakevych A.M., Timchenko V.M. ta in. / za red. V.Ya. Shevchuka. K.: KSP, 1999. 182 C.

Основные стадии и закономерности формирования берегов крупных равнинных водохранилищ Дубняк С.С.

На основе анализа многолетней динамики развития берегов днепровских и других крупных равнинных водохранилищ рассмотрены основные стадии фоормирования берегов и соответствующие им типологические характеристики. Показана роль исходного рельефра и геологического строения речной долины в развитии береговых процессов. Отмечена условность стадии динамического равновесия для берегов водохранилищ и возрастающая роль вдольбереговых течений и связанных с ними потоков наносов и динамических систем берегов. Проанализировано основные закономерности процессов фрормирования берегов - наследственность, направленность, инерционность и изменчивость развития.

Ключевые слова: водохранилище, береговая зона, стадии развития, абразионно-аккумулятивные процессы, динамические системы берегов, наследственность и направленность процесса.

\title{
Main stages and regularities of coast formation of large plain reservoirs
}

Dubnyak S.S.

The main stages of the reservoir coast formation and their typological characteristics are considered on the base of the analysis of long-term monitoring studies of the Dnieper reservoirs coast dynamics, as well as generalization of published materials on other large plain reservoirs. It is shown that the common scheme of periodization of the shoreline development manifested itself only in the two stages: abrasion and abrasion-accumulative leveling, and therefore it is premature to claim the general stabilization of the coast formation process. The conventionality of the dynamic equilibrium stage for the coast of reservoirs and the growing role of coastal currents and associated sediment flows and dynamic coast systems are noted. The current state of the coasts of large plain reservoirs is estimated as the beginning of the stabilization phase on the coasts with sufficient sand materials. On the coasts composed of loess, clay or loams the processes of intensive transformation are continued. The analysis of the direction of development of the coastal zone showed three stages of change of shore profile and plan: intensive formation, stabilization and the final stage of attenuation according to the leading factors. Active accumulation means the transition to the stage of abrasion-accumulative leveling, and the emergence of dynamic coast systems and activation of coastal sediment flows means the transition to the dismemberment of the shoreline by accumulative forms. The main regularities of development of coast formation processes - heredity, direction, inertia and variability are analyzed. The heredity means that the geographical and geological conditions which developed before the filling of the reservoir are played the leading role in these processes. The direction of development is associated with an increase of the erosion base and its consequence - the leveling of the coastal zone relief. The orientation of the general process of coast formation to achieve a state of dynamic equilibrium includes stages of inertia and variability. Inertial states are the certain periods when a certain set of factors and conditions and corresponding to them type of coast prevails. Variability is a change in factors and conditions, as a result of which new types of shores or fluctuations in the characteristics of the coastal zone (movement of shoals and dynamic coastal systems, seasonal changes in shore profiles) are formed.

Keywords: reservoir, coastal zone, stages of development, abrasion-accumulative processes, dynamic coastal systems, heredity and direction of the process.

Надійшла до редколегії 30.07.2021

DOI: https://doi.org/10.17721/2306-5680.2021.3.4

УДК 556.5.06

Корнієнко В.О., Ободовський О.Г., Лук'янець О.І.

Київський національний університет імені Тараса Шевченка

\section{ОЦІНКА БАГАТОРІЧНОЇ МІНЛИВОСТІ СЕРЕДНЬОГО РІЧНОГО СТОКУ ВОДИ РІЧОК БАСЕЙНУ ПРИП'ЯТІ В МЕЖАХ УКРАЇНИ ТА ЙОГО РОЗРАХУНКОВІ ХАРАКТЕРИСТИКИ У ФАЗИ ВОДНОСТІ}

Вивчення циклічності багаторічних коливань стоку води річок, що сприяє встановленню багаторічної динаміки водності та потенційних (прогнозних) їі змін - актуальне питання сучасних гідрологічних досліджень. Для опису багаторічної мінливості стоку води річок та їі структури (циклів та фраз водності) найбільш ефрективним методом є стохастичний, що грунтуються на математичній статистиці, теорії випадкових величин та функцій, теорії ймовірностей. Для виявлення стохастичних закономірностей багаторічної мінливості використано автокореляційний аналіз, різноманітні критерії-статистики (однорідності, серій, довжини серій), сумарні та різницеві інтегральні криві, теорія ймовірностей, кореляційні 
зв'язки, статистична оцінка ймовірних похибок тощо. За результатами дослідження багаторічної мінливості середнього річного водного стоку річок басейну р. Прип'ять в межах України, встановлено, що

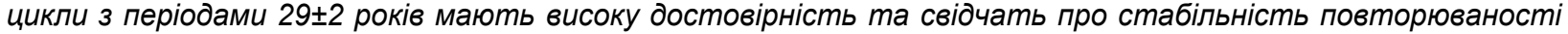

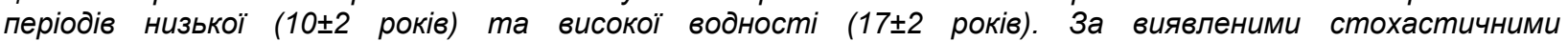
закономірностями передбачається, що до 2025-26 рр. варто очікувати продовження маловодної фрази водності, після цього з тривалістю 16-17 років розпочнеться багатоводна фраза і з 2044-45 рр. знову буде маловоддя до 2055-56 рр. За запропонованими рівняннями регресії між середньорічними витратами води за багаторічний період та їхніми середніми значеннями в період багатоводної і маловодної фраз водності та отриманими перехідними коефріцієнтами можна встановити розрахункові характеристики стоку різної забезпеченості у фрази водності, тим самим дати й їх прогнозні оцінки.

Ключові слова: середньорічний стік, багаторічна мінливість, цикли та фрази водності, стохастичні закономірності, прогнозні оцінки, річка Прип'ять, річки басейну Прип'яті в межах України.

Вступ. Багаторічна мінливість водного стоку річок пов'язана, в першу чергу, 3 ймовірнісним характером його змін у часі, виявлення закономірностей якої проявляється у коливаннях стоку. Для досліджень багаторічних коливань водного стоку річок використовуються різноманітні методи, як детерміновані, що ґрунтуються на вивченні процесів формування стоку, так й стохастичні - на математичній статистиці, теорії випадкових величин та функцій, теорії ймовірностей $[1,8]$.

Річковий стік води - це комплексний показник впливу різноманітних, багаточисельних факторів довкілля, які залучені до його фрормування та сполучення яких має випадковий характер. Тому випадковість притаманна й стоку води річок, яка обумовлена не тільки багатофакторністю цього процесу, а й обмеженістю даних спостережень, певними змушеними припущеннями про механізм його формування тощо. Дослідження стохастичних закономірностей у багаторічної мінливості стоку води річок $є$ найбільш ефективним для опису її структури з виділенням циклів та фраз водності [2, 5, 9].

Вивчення циклічності багаторічних коливань стоку води річок, що сприяє встановленню багаторічної динаміки водності та потенційних (прогнозних) їі змін актуальне питання сучасних гідрологічних досліджень.

Мета роботи - на основі виявлених стохастичних закономірностей у багаторічної мінливості середнього річного стоку води річок української частини басейну Прип'яті провести оцінку його розрахункових характеристик у багатоводну та маловодну фрази водності.

Вихідні дані. В басейні р. Прип'ять в межах України нараховується 28 гідрологічних постів, на яких проводять спостереження за стоком води. В основному, на притоках 3 площами водозборів від 141 до 13300 км² та з періодами спостереження від 33 до 80 років.

Для виявлення стохастичних закономірностей у досліджені багаторічних коливань водного стоку доцільно використовувати тривалі ряди спостережень за стоком води 3 великими площами водозборів, які виключають вплив азональних проявів місцевих умов, випадкових фракторів та показують в цілому основні тенденції часової мінливості стоку води на великій території річкового басейну [3, 6, 10, 12]. Тому, для опису структури мінливості середнього річного стоку води річок української частини Прип'яті в дослідженні використані ряди спостереження за даними гідрологічного поста р. Прип'ять - м. Мозир, що розташований на території Республіки Білорусь та $є$ замикальним створом водозбору

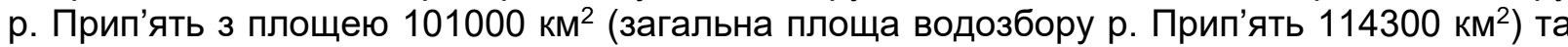
тривалим періодом спостережень з 1882 по 2019 рр. (138 років).

В межах гирлової ділянки р. Прип'ять на території України відсутні гідрологічні пости, де проводять спостереження за стоком води з достатньою часової тривалістю рядів [4].

Базовий досліджуваний ряд середньорічних витрат води р. Прип'ять - м. Мозир перевірено на статистичну однорідність, в результаті встановлено, що прийняті нульові гіпотези критеріїв Стьюдента, Фішера та Вількоксона при рівні значущості $2 \alpha=5 \%$ не спростовуються. Це добре прослідковується й за сумарною інтегральною кривою, де на відповідному графіку (рис.1) наочно видно, що різких переломних точок на збільшення чи зменшення середнього річного стоку води в багаторічному розрізі немає, що свідчить про однорідність досліджуваного ряду та відсутність кардинальних змін. 


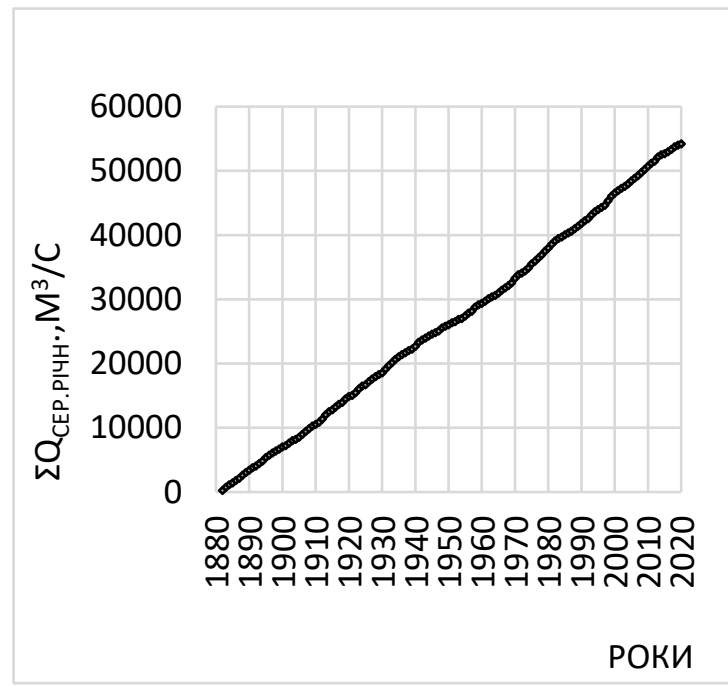

Puc. 1. Сумарна інтегральна крива середньорічних витрат води р.Прип'ять -м. Мозир

Результати дослідження. Як слід 3 вищезазначеного, аналіз багаторічних мінливості середнього стоку води річок досліджуваної території передбачає виявлення структури часових коливань стоку води (циклів та фаз водності) р. Прип'ять за даними гідрологічного поста м. Мозир з подальшою оцінкою просторової специфріки змін водності на річках басейну.

Для фрормалізації багаторічних коливань річного водного стоку досліджуваної території у вигляді циклів водності та оцінювання їх кількісних показників, насамперед, тривалості, було застосовано автокореляційний аналіз часових послідовностей середньорічних витрат води р. Прип'ять - м. Мозир. В результаті такого аналізу отримали автокореляційну функцію $R(t, \tau)$, яка показує статистичну внутрішню кореляцію між членами ряду спостережень, упорядкованих у часі (рис.2).

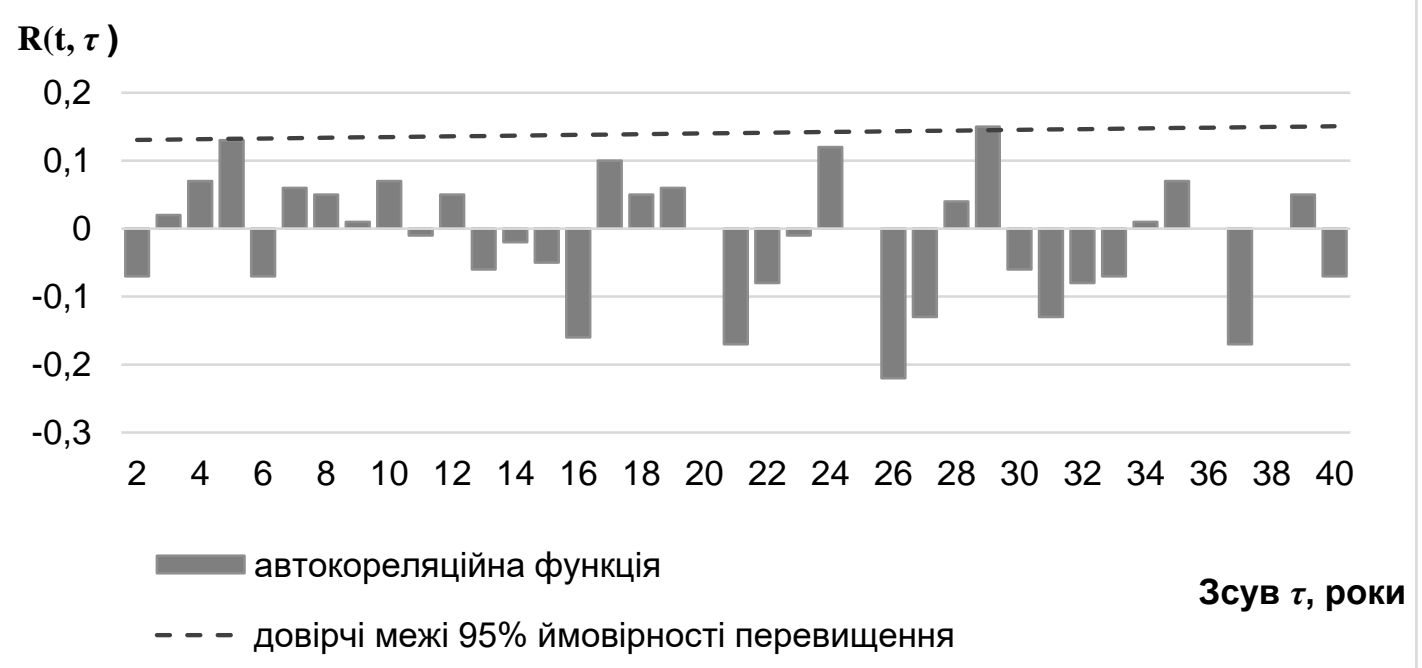
М. Мозир

Puc 2 Корелограма часових послідовностей середньорічних витрат води р. Прип'ять -

Слід відмітити, що для вибору часового параметру $\tau$ - крок часового зсуву між перерізами, пропонуються різні співвідношення від довжини послідовності $N[1,8,11]$. В практиці гідрологічних розрахунків, враховуючи специфіку рядів стоку води, $\tau=1 /(3 \leftrightarrow 4)$. Тобто, в нашому випадку, для отримання достовірних результатів значення часового зсуву приймались в межах від 2 до 40 років [7], оскільки довжина реалізації послідовності середньорічних витрат води р. Прип'ять - м. Мозир дорівняє 138 років (1882-2019р.).

Для визначення статистичної значущості визначених ординат автокореляційної фрункції було попередньо розраховано довірчі межі (ДМ $R(t, \tau)$ ) 95\% ймовірності перевищення в рамках прийнятої області реалізації - нижня межа (для $\tau=2)$ ДМ $R(t, \tau)=0,13$, верхня межа (для $\tau=40)$ ДМ $R(t, \tau)=0,15$. 
Проаналізувавши закономірний хід функцій $R(t, \tau)$ (рис. 2), яка в залежності від величини зсуву приймає додатні або від'ємні значення, в довірчі межі 95\% ймовірності перевищення потрапляють ординати, що відповідають крокам часового зсуву 5 та 29 років. Це свідчить про те, що існують подібні тенденції коливань стоку води кожні 5 та 29 років.

Таким чином, переважаючий цикл, що відображає більш-менш тривалі природні коливання середньорічних витрат води р. Прип'ять-м.Мозир становить 29 років.

Для перевірки статистичної достовірності існування періодів (фаз) підвищеної та пониженої водності, застосовано критерій серій за статистикою tи. [1,11]. Під серією розуміють будь-яку ділянку послідовності $N$, що складається з елементів одного й того ж роду. В нашому випадку до першої групи серій з елементів відносилися члени послідовності, значення яких перевищують вибіркове середнє, а до другої - серії 3 елементів, значення яких менше його. Для досліджуваного ряду середньорічних витрат води були обраховані розрахункові параметри за критерієм серій та його статистика, що складає $t u=2,56$. При рівні значущості $\alpha=1 \%$ статистика критерію не перевищила критичне значення і попала в довірчі межі, що свідчить про статистично достовірну тенденцію до утворення угрупувань (серій) підвищених і понижених значень у досліджуваної послідовності.

В якості тестової статистики тривалості підвищених або понижених угрупувань років використана статистика найбільшої довжини серій $K[1,8,12]$. Для підтвердження гіпотези значення статистики $K$ (емпірична величина) порівнюється 3 аналітичним $K \alpha$ при рівні значимості $\alpha$. За даними спостережень середньорічних витрат води на р. Прип'ять-м. Мозир чітко виділяється довжини понижених угрупувань, що складає $\approx 10$ років (наприклад, з 1896 по 1905 рр.), тобто емпіричне значення статистики $K=10$. Враховуючи, що період спостережень складає 138 років, то аналітичне значення статистики найбільшої довжини серій $K \alpha=10,4$ (при рівні значимості $2 \alpha=5 \%$ ). Порівнявши $K$ та $K \alpha$, отримали $K<K \alpha$, що підтверджує існування тенденції до угрупувань у послідовностях середньорічного стоку води і вони вважаються статистично достовірними. Таким чином, теоретично доведено, що угрупування маловодних років можуть складати $10 \pm 2$ років.

За виявленими стохастичними закономірностями у коливаннях середньорічного стоку води р. Прип'ять-М. Мозир визначено повторюваність циклу, що складає $29 \pm 2$ років та в

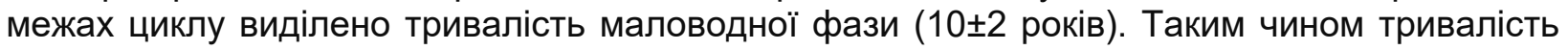

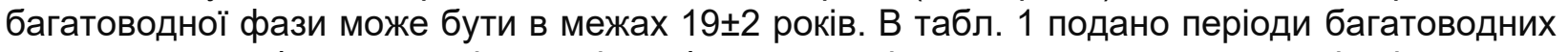
та маловодних фраз, середні за періоди фраз водності витрати води та прогнозні оцінки стоку р. Прип'ять-м. Мозир на період до 2056 року з вказівкою стандартних відхилень у фразі водності.

Таблиця 1. Середні за періоди фаз водності витрати води р. Прип'ять - м. Мозир та прогнозні оцінки стоку на період до 2056 року

\begin{tabular}{|c|c|c|c|c|c|c|c|c|c|c|c|c|}
\hline $\begin{array}{l}\text { Характе- } \\
\text { ристика }\end{array}$ & \multicolumn{9}{|c|}{ За даними спостережень } & \multicolumn{3}{|c|}{$\begin{array}{c}\text { Прогнозні оцінки } \\
\text { (士 стандартне } \\
\text { відхилення) }\end{array}$} \\
\hline $\begin{array}{c}\text { Період } \\
\text { (роки) }\end{array}$ & $\begin{array}{c}1882- \\
1989\end{array}$ & $\begin{array}{l}1899- \\
1911\end{array}$ & $\begin{array}{l}1912- \\
1927\end{array}$ & $\begin{array}{l}1928- \\
1939\end{array}$ & $\begin{array}{l}1940- \\
1958\end{array}$ & $\begin{array}{l}1959- \\
1968\end{array}$ & $\begin{array}{r}1969 \\
1985\end{array}$ & $\begin{array}{l}1986- \\
1997\end{array}$ & $\begin{array}{l}1998- \\
2013\end{array}$ & $\begin{array}{r}2014- \\
2025-26\end{array}$ & $\begin{array}{c}2026- \\
2042-43\end{array}$ & $\begin{array}{c}2044- \\
2055-56\end{array}$ \\
\hline $\begin{array}{c}\text { Фаза } \\
\text { водності }\end{array}$ & $\uparrow$ & $\downarrow$ & $\uparrow$ & $\downarrow$ & $\uparrow$ & $\downarrow$ & $\uparrow$ & $\downarrow$ & $\uparrow$ & $\downarrow$ & $\uparrow$ & $\downarrow$ \\
\hline $\begin{array}{l}\text { Середня за } \\
\text { періоди } \\
\text { водності } \\
\text { витрата, }{ }^{3} / \mathrm{c}\end{array}$ & 373 & 345 & 423 & 385 & 346 & 334 & 464 & 382 & 471 & $362 \pm 50$ & $412 \pm 70$ & $362 \pm 50$ \\
\hline
\end{tabular}

Примітка. *Фази водності - $\uparrow$ багатоводна, $\downarrow$ маловодна

Для з'ясування характеру мінливості стоку води в межах української частини басейну Прип'яті побудовано суміщені різницеві інтегральні криві середніх річних витрат води річок, що знаходяться на досліджуваної території та р. Прип'ять - м. Мозир, як замикального створу (рис. 3). Аналіз показав, що внутрішні циклічні коливання водності річок, що знаходяться в межах української частини басейну р. Прип'ять мають ідентичну структуру. 


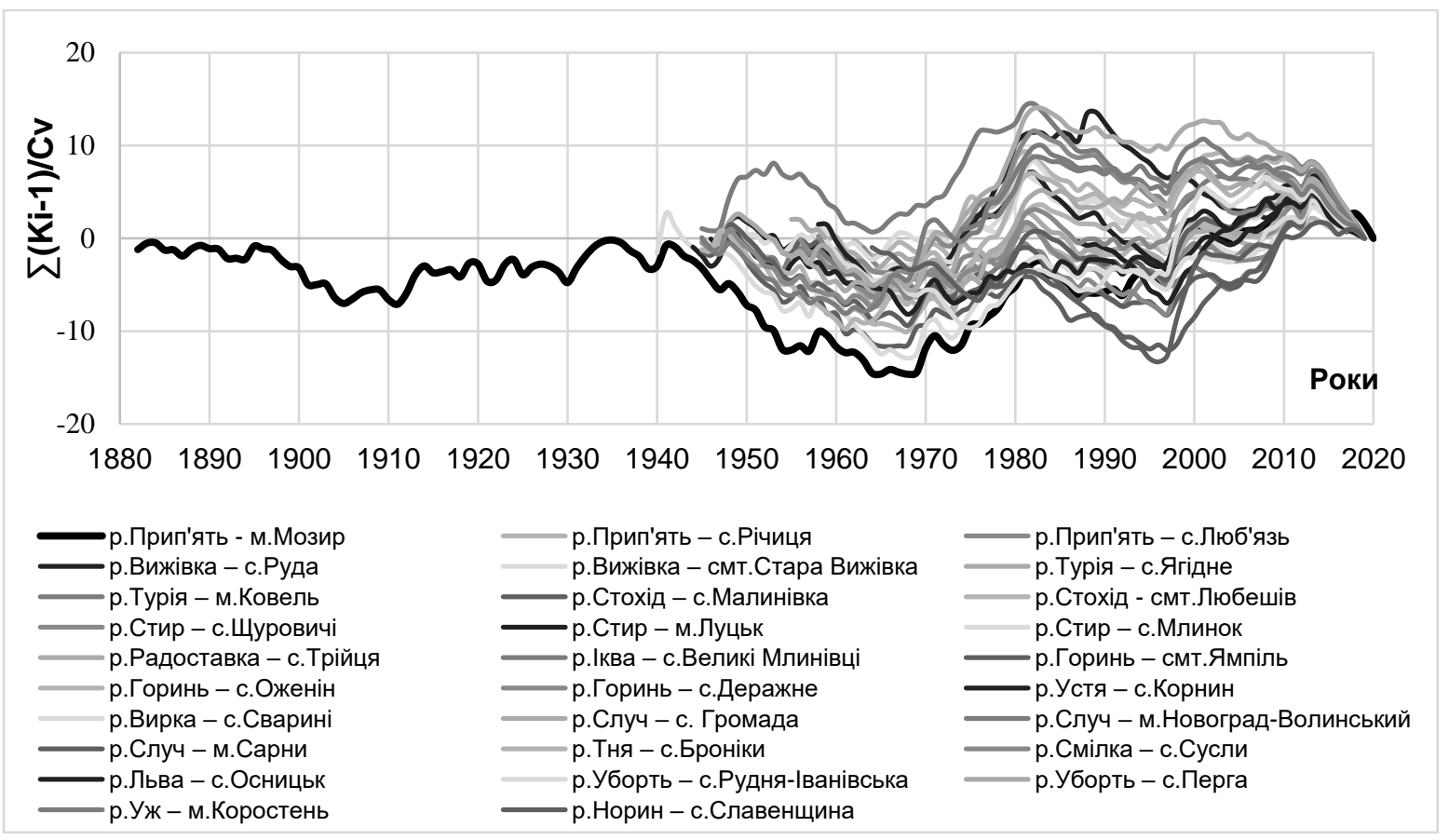

Рис 3. Суміщені різницеві інтегральні криві середніх річних витрат води р. Прип'ять - м. Мозир та річок, що знаходяться в межах української частини басейну р. Прип'ять

Використовуючи межі багатоводних та маловодних фраз, що встановлені для $p$. Прип'ять - м. Мозир, визначено для річок для річок української частини басейну р. Прип'ять, на яких ведуться спостереження за водним стоком, середні витрати води в період цих фраз водності Для відображення змін стокових складових у цілому з часом на рис. 4 показана гістограма з накопиченням витрат води у періоди водності по основним річкам у замикальних створах в межах досліджуваної території.

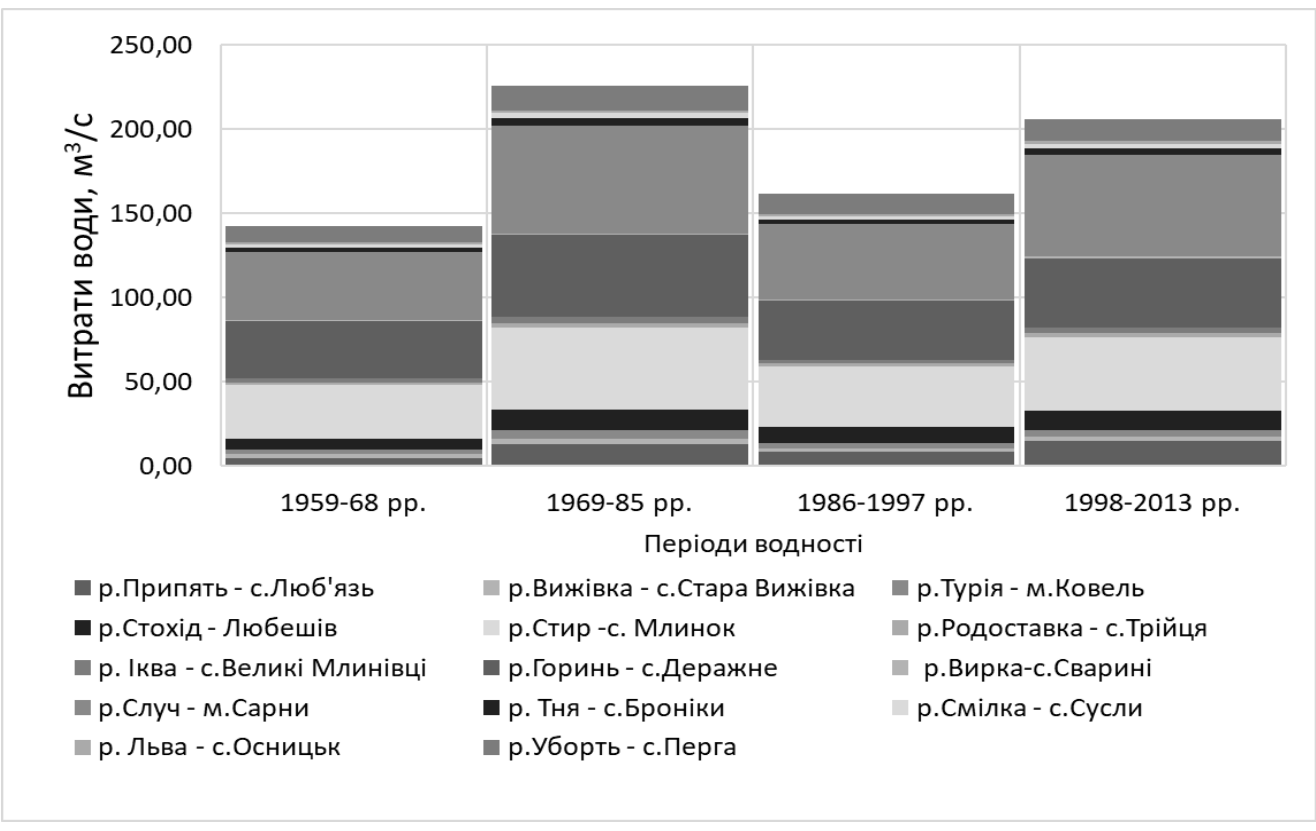

Рuc. 4. Гістограма накопичення середніх річних витрат води за виділеними періодами водності річок в басейні Прип'яті в межах України 
Як бачимо з рис. 3-4 для всіх річок басейну р. Прип'ять в межах України виділяється циклічна мінливість, багатоводні та маловодні фази водності, які є подібними.

Для узагальнення структури багаторічної мінливості середнього річного стоку води річок басейну Прип'яті в межах України побудовано кореляційні залежності середніх багаторічних витрат води річок досліджуваної території та їх значень в періоди багатоводних та маловодних фаз водності (рис. 5).

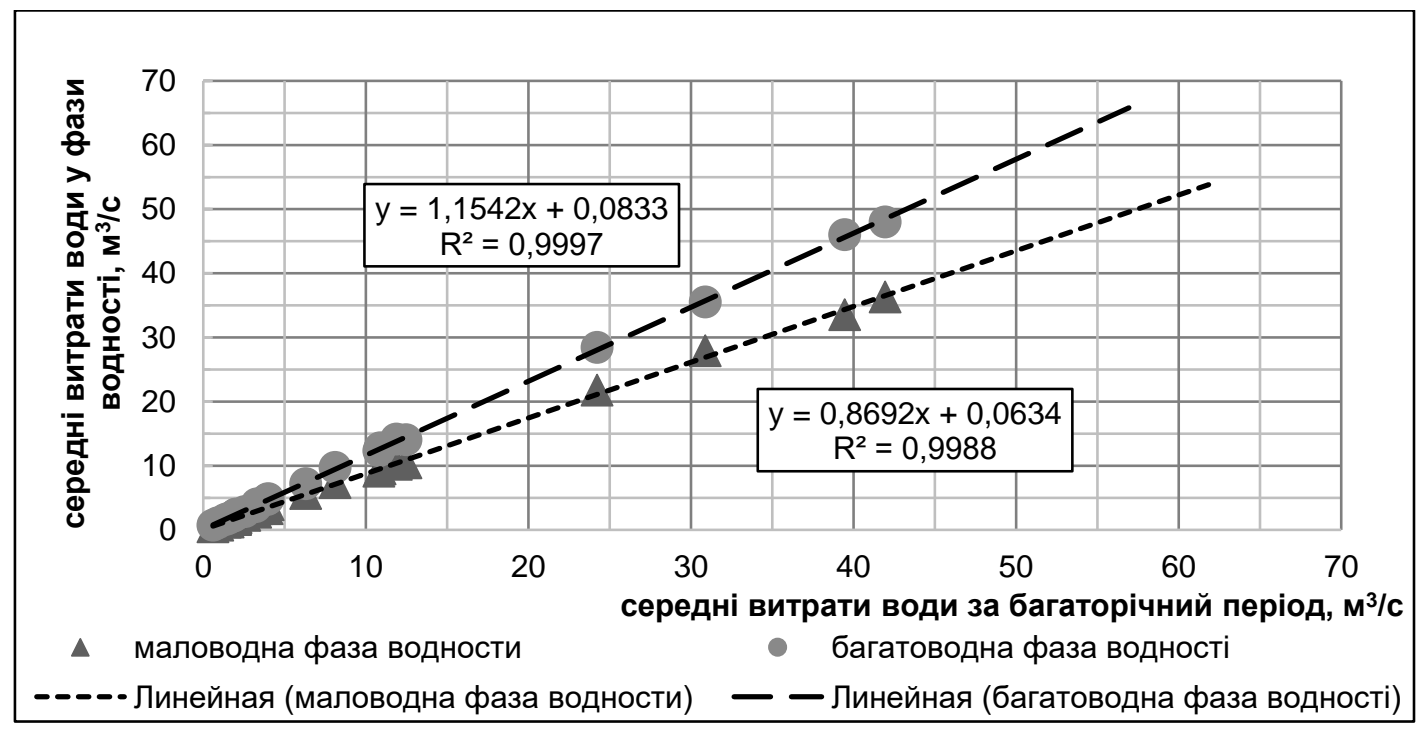

Рuc 5. Співвідношення середніх витрат води річок р. Прип'ять в межах України у періоди багатоводних та маловодних фаз від середніх багаторічних їх значень

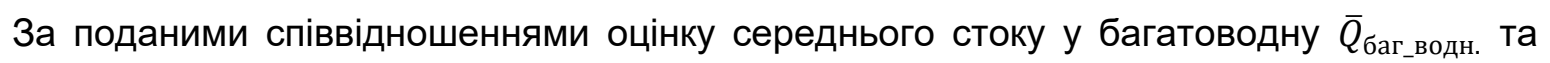
маловодну $\bar{Q}_{\text {мал_водн. }}$ фази за середньою багаторічною витратою води можна проводити за рівняннями регресії з високим рівнем апроксимації $R^{2}$ :

$$
\begin{aligned}
& \bar{Q}_{\text {баг_водн. }}=1,1542 \bar{Q}+0,0833, \\
& \bar{Q}_{\text {мал_водн. }}=0,8692 \bar{Q}+0,0634 .
\end{aligned}
$$

Було розраховано ймовірні похибки визначення середніх витрат води у багатоводні та маловодні періоди та проведено осереднення їх значень (табл. 4). Вони подані у відсотках та визначаються за пропорцією від значень середніх витрат води у відповідну фразу водності.

Таблиця 2. Ймовірне відхилення розрахункових величин середньорічного стоку води багатоводних та маловодних фаз для річок р. Прип'ять в межах України

\begin{tabular}{|c|c|c|}
\hline \multirow{2}{*}{$\begin{array}{c}\text { річки басейну } \\
\text { р. Прип'ять в межах України }\end{array}$} & \multicolumn{2}{|c|}{ Ймовірне відхилення величин стоку води, \% } \\
\cline { 2 - 3 } & багатоводна фаза & маловодна фаза \\
\cline { 2 - 3 } & $\pm 2,12$ & $\pm 5,04$ \\
\hline
\end{tabular}

Запропоновані рівняння регресії (1-2) були перевірені за даними спостережень за середніми річними витратами води попередніх років на 25 гідрологічних постах 3 визначенням показника ймовірності перевищення допустимого відхилення. Забезпеченість прогнозних оцінок для річок басейну р. Прип'ять в межах України в середньому для багатоводних періодів склала $82 \%$, для маловодних - 77\%. Ці відсотки показують, що прогнозі оцінки за запропонованими рівняння можна віднести до категорії «добрих» та «задовільних» відповідно. Випадки, коли не справдились прогнозні оцінки, переважно 
відносяться до дуже малих водозборів чи з суттєвим впливом водогосподарської діяльності на стік води річок.

Високий рівень апроксимації запропонованих рівнянь та значущість побудованих залежностей дало змогу узагальнити для річок р. Прип'ять в межах України ймовірні значення середніх витрат води, які можна очікувати у періоди багатоводної та маловодної фрази циклу, в залежності від їх середніх багаторічних значень (табл. 3).

Таблиця 3. Приклад переходу від середніх річних витрат води (багаторічних значень) до їх величин інших забезпеченостей в періоди маловодної та багатоводної фаз водності для річок басейну р. Прип'ять в межах України за допомогою перехідних коефіцієнтів

\begin{tabular}{|c|c|c|c|c|c|c|c|c|c|c|c|c|c|}
\hline \multicolumn{14}{|c|}{ Ймовірність перевищення (забезпеченість), \% } \\
\hline 0,01 & 0,10 & 1,00 & 3,00 & 5,00 & 10 & 25 & 50 & 75 & 90 & 95 & 97 & 99 & 99,9 \\
\hline \multicolumn{14}{|c|}{ Середнє значення перехідних коефіцієнтів за багаточний період $K_{p}$} \\
\hline 3,31 & 2,77 & 2,19 & 1,89 & 1,75 & 1,54 & 1,23 & 0,94 & 0,71 & 0,54 & 0,45 & 0,40 & 0,33 & 0,28 \\
\hline \multicolumn{14}{|c|}{ Значення перехідного коефріцієнту К кмалов. в період маловодної фрази } \\
\hline 2,68 & 2,24 & 1,77 & 1,52 & 1,41 & 1,24 & 0,98 & 0,75 & 0,56 & 0,42 & 0,35 & 0,31 & 0,25 & 0,21 \\
\hline \multicolumn{14}{|c|}{ Значення перехідного коефіцієнту Крбагатовод, в період багатоводної фази } \\
\hline 3,73 & 3,13 & 2,48 & 2,14 & 1,98 & 1,75 & 1,40 & 1,08 & 0,82 & 0,63 & 0,53 & 0,47 & 0,39 & 0,34 \\
\hline
\end{tabular}

Отримані результати (табл.3) можна використати для прогнозних оцінок можливих значень характеристик середньорічного стоку в періоди багатоводної та маловодної фаз водності будь-якої річки р. Прип'ять в межах України.

Застосувавши розраховані коефіцієнти Кр переходу від середніх річних витрат води (багаторічних значень) до їх величин інших забезпеченостей для річок басейну р. Прип'ять в межах України можна очікувати відповідні значення середньорічного стоку води в періоди багатоводної та маловодної фраз певної забезпеченості (табл.3).

Таким чином, для річок р. Прип'ять в межах України можна використовувати осереднені значення перехідних коефіцієнтів $K_{p}$ від середньорічних річних витрат води до їх ймовірних величин інших забезпеченостей в періоди багатоводної та маловодної фаз водності.

Висновки. За результатами дослідження стохастичних закономірностей багаторічної мінливості середнього річного водного стоку річок басейну Прип'яті в межах України, що супроводжувалось аналізом циклічності багаторічних коливань та їх структури, встановлено, що цикли з періодами $29 \pm 2$ років мають високу достовірність та свідчать про

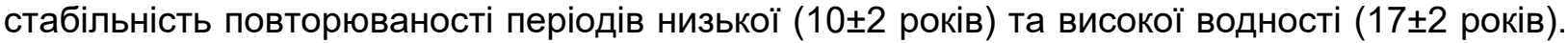
За виявленими стохастичними закономірностями передбачається, що до 2025-26 рр. варто очікувати продовження маловодної фрази водності, після цього з тривалістю 16-17 років розпочнеться багатоводна фраза і з 2044-45 pр. знову буде маловоддя до 2055-56 pp.

За запропонованими рівняннями регресії зі значною апроксимацією між середньорічними витратами води за багаторічний період та їхніми середніми значеннями в період багатоводної і маловодної фраз водності та отриманими перехідними коефіцієнтами можна встановити розрахункові характеристики стоку різної забезпеченості у фрази водності, тим самим дати й їх прогнозі оцінки.

\section{Список літератури.}

1. Картвелишвили H. А. Стохастическая гидрология: монография. Ленинград : Гидрометеоиздат, 1975. 162 с.

2. Лук'янець О.І., Камінська Т.П. Закономірності та просторова синхронність багаторічних циклічних коливань водного стоку річок Українських Карпат. Науковий вісник Чернівецького університету: збірник наукових праць. Чернівці: Чернівецький нац. ун-т.: Географія. 2015. Вип. 744745 c. $18-24$.

3. Лук'янець О.І., Сосєдко М.М. Багаторічні коливання водності в Карпатах. Матеріали міжнародної конференції “Стихійні явища у Карпатах”. Рахів. 1999. с.195-199. 
4. Лукьянец О.И., Корниенко В.А. Расчетные характеристики среднего годового стока воды рек правобережной части Припяти. Сборник материалов Международной научно-практической конференции «Актуальные проблемы наук о Земле: использование природных ресурсов и сохранение окружающей среды». БрГУ имени А. С. Пушкина, 2017. Часть 1. с. 180-183.

5. Ободовський О. Г., Лук'янець О. І. Виявлення та прогнозна оцінка коливань водності річок Карпатського регіону. Матеріали Міжнар. наук. конф. «Від географії до географічного українознавства: еволюція освітньо-наукових ідей та пошуків (до 140-річчя започаткування географії у Чернівецькому національному університеті ім. Ю. Федьковича)». Чернівці: Чернів. нац. ун-т. 2016. c. $170-171$.

6. Сосєдко М.М. Лук'янець О. І. Можливості оцінювання річкового стоку в Карпатах на найближчі роки з урахуванням його багаторічних коливань. Наук. праці УкрНДГМІ. 1998. Вип. 246. С. 46-55.

7. Сусідко М.М. Лук’янець О. І. Багаторічні коливання водності в Україні. Гідрологія, гідрохімія і гідроекологія. 2010. Т. 4. с. 34-40.

8. Христофроров А. В. Теория случайних процесов в гидрологии: монография. Москва: МГУ 1994. 143 c.

9. Lukianets O., Obodovskyi O., Grebin V., Pochaievets O. Time series analysis and forecast estimates of the mean annual water runoff of rivers in of the Prut and Siret basins (within Ukraine). Electronic book with full papers from XXVIII Conference of the Danubian Countries on Hydrological Forecasting and Hydrological Bases of Water Management. Kyiv. 2019. p. 133-139.

10. Lukianets O., Obodovskyi I. Spatial, Temporal and Forecast Evaluation of Rivers' Streamflow of the Drainage Basin of the Upper Tisa under the Conditions of Climate Change. Environmental Research, Engineering and Management. 2015. No. 71 (1). p. 36-46.

11. Lukianets $O$. Stochastic regularities of long-term fluctuation of average annual runoff of rivers of Tisza river basin (within the Ukraine). Electronic Book with full papers from XXVII Conference of Danubian Countries on the hydrological forecasting and hydrological bases of water management. 2017. Golden Sands. Bulgaria. p. 280-290.

12. Obodovskyi O., Lukianets O. Patterns and Forecast of Long-term Cyclical Fluctuations of the Water Runoff of Ukrainian Carpathians Rivers. Environmental Research, Engineering \& Management. 2017. Vol. 73 No.1. p. 33-47 DOl: https://doi.org/10.5755/j01.erem.73.1.15799.

\section{References}

1. Kartvelishvili N. A. Stokhasticheskaya gidrologiya: monografiya [Stochastic hydrology: a monograph] Leningrad: Gidrometeoizdat, 1975. 162 s.

2. Lukianets O.I., Kaminska T.P. Zakonomirnosti ta prostorova synkhronnist' bahatorichnykh tsyklichnykh kolyvan' vodnoho stoku richok Ukrayins'kykh Karpat[Regularities and spatial synchronicity of long-term cyclic fluctuations of water runoff of rivers of the Ukrainian Carpathians]Naukovyy visnyk Chernivets'koho universytetu: zbirnyk naukovykh prats'. Chernivtsi: Chernivets'kyy nats. un-t.: Heohrafiya. 2015. Vyp. 744-745 s. 18-24.

3. Lukianets O.I., Sosedko M.M. Bahatorichni kolyvannya vodnosti v Karpatakh [Perennial water fluctuations in the Carpathians]. Materialy mizhnarodnoyi konferentsiyi "Stykhiyni yavyshcha u Karpatakh". Rakhiv. 1999. s.195-199.

4. Lukianets O.I., Korniienko V.A. Raschetnyye kharakteristiki srednego godovogo stoka vody rek pravoberezhnoy chasti Pripyati [Estimated characteristics of the average annual water runoff of the rivers of the right-bank part of Pripyat]. Cbornik materialov Mezhdunarodnoy nauchno-prakticheskoy konferentsii «Aktual'nyye problemy nauk o Zemle: ispol'zovaniye prirodnykh resursov i sokhraneniye okruzhayushchey sredy». BrGU imeni A. S. Pushkina, 2017. Chast' 1. s. 180-183.

5. Obodovskyi O. H., Lukianets O. I. Vyyavlennya ta prohnozna otsinka kolyvan' vodnosti richok Karpat.s'koho rehionu [Detection and forecast assessment of water fluctuations of rivers in the Carpathian region]. Materialy Mizhnar. nauk. konf. «Vid heohrafiyi do heohrafichnoho ukrayinoznavstva: evolyutsiya osvitn'o-naukovykh idey ta poshukiv (do 140-richchya zapochatkuvannya heohrafiyi u Chernivets'komu natsional'nomu universyteti im. YU. Fed'kovycha)». Chernivtsi: Cherniv. nats. un-t. 2016. s. 170-171.

6. Sosedko M. M. Lukianets O. I. Mozhlyvosti otsinyuvannya richkovoho stoku $v$ Karpatakh na nayblyzhchi roky z urakhuvannyam yoho bahatorichnykh kolyvan [Possibilities of estimating river runoff in the Carpathians for the coming years, taking into account its long-term fluctuations]. Nauk. pratsi UkrNDHMI. 1998. Vyp. 246. S. 46-55.

7. Susidko M. M. Lukianets O. I. Bahatorichni kolyvannya vodnosti v Ukrayini [Perennial water fluctuations in Ukraine]. Hidrolohiya, hidrokhimiya i hidroekolohiya. 2010. T. 4. s. 34-40.

8. Khristoforov $A$. V. Teoriya sluchaynykh protsessov v gidrologii: monografiya [Theory of random processes in hydrology: monograph]. Moskva: MGU. 1994. 143 s. 
9. Lukianets O., Obodovskyi O., Grebin V., Pochaievets O. Time series analysis and forecast estimates of the mean annual water runoff of rivers in of the Prut and Siret basins (within Ukraine). Electronic book with full papers from XXVIII Conference of the Danubian Countries on Hydrological Forecasting and Hydrological Bases of Water Management. Kyiv. 2019. p. 133-139.

10.Lukianets O., Obodovskyi I. Spatial, Temporal and Forecast Evaluation of Rivers' Streamflow of the Drainage Basin of the Upper Tisa under the Conditions of Climate Change. Environmental Research, Engineering and Management. 2015. No. 71 (1). p. 36-46.

11. Lukianets $O$. Stochastic regularities of long-term fluctuation of average annual runoff of rivers of Tisza river basin (within the Ukraine). Electronic Book with full papers from XXVII Conference of Danubian Countries on the hydrological forecasting and hydrological bases of water management. 2017. Golden Sands. Bulgaria. p. 280-290.

12.Obodovskyi O., Lukianets O. Patterns and Forecast of Long-term Cyclical Fluctuations of the Water Runoff of Ukrainian Carpathians Rivers. Environmental Research, Engineering \& Management. 2017. Vol. 73 No.1. p. 33-47 DOI: https://doi.org/10.5755/j01.erem.73.1.15799.

Оценка многолетний изменчивости среднего годового стока воды рек бассейна Припяти по украине и его расчетные характеристики в фазы водности

Корниенко В.А., Ободовський А. Г., Лукьянец О.И.

Изучение цикличности многолетних колебаний стока воды рек, способствует установлению многолетней динамики водности и потенциальных (прогнозных) ее изменений - актуальный вопрос современных гидрологических исследований. Для описания многолетней изменчивости стока воды рек и ее структуры (циклов и фраз водности) наиболее эффрективным методом является стохастический, основанные на математической статистике, теории случайных величин и фрункций, теории вероятностей. Для выявления стохастических закономерностей многолетней изменчивости использовано автокорреляционной анализ, различные критерии-статистики (однородности, серий, длины серий), суммарные и разностные интегральные кривые, теория вероятностей, корреляционные связи, статистическая оценка вероятных ошибок и тому подобное. По результатам исследования многолетней изменчивости среднего годового водного стока рек бассейна р. Припять в пределах Украины, установлено, что циклы с периодами $29 \pm 2$ лет имеют высокую достоверность и свидетельствуют о стабильности

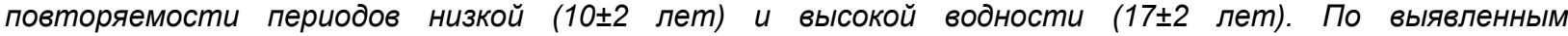
стохастическими закономерностями предполагается, что к 2025-26 г2. следует ожидать продолжения маловодной фразы водности, после этого с продолжительностью 16-17 лет начнется многоводная фраза и с 2044-45 г2. вновь будет маловодье в 2055-56 ге. По предложенным уравнениями регрессии между среднегодовыми расходами воды за многолетний период и их средними значениями в период многоводной и маловодной фраз водности и полученными переходными коэфрфициентами можно установить расчетные характеристики стока различной обеспеченности в фразы водности, тем самым дать и их прогнозе оценки.

Ключевые слова: среднегодовой сток, многолетняя изменчивость, циклы и фразы водности, стохастические закономерности, прогнозные оценки, река Припять, реки бассейна Припяти в пределах Украины.

Estimation of long-term variability of the average annual water runoff of the rivers of the Pripyat basin in Ukraine and its calculated characteristics in the phases of water content

Korniienko V., Obodovskyi O., Lukianets $O$.

The aim of the study was to analyze the long-term variability of the average annual water runoff of the rivers of the Pripyat basin within Ukraine and to assess its calculated characteristics in the high-water and low-water phases of water content. The research of the cyclical nature of long-term fluctuations of river water flow, which contributes to the establishment of long-term dynamics of water content and potential (forecast) changes - is a topical issue of modern hydrological research. To describe the long-term variability of river water flow and its structure (cycles and phases of water content) the most effective method is stochastic, based on mathematical statistics, the theory of random variables and functions, probability theory. Autocorrelation analysis, various statistical criteria (homogeneity, series, series lengths), total and difference integral curves, probability theory, correlations, statistical estimation of probable errors, etc. were used to identify stochastic regularities of long-term variability. According to the results of the study of longterm variability of the average annual water runoff of the rivers of the Pripyat basin within Ukraine, it is established that cycles with periods of $29 \pm 2$ years have high reliability and indicate stability of periods of low (10 \pm 2 years) and high

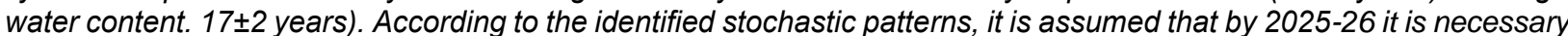
to expect the continuation of the low-water phase of water, then with the duration of 16-17 years the high-water phase will begin and from 2044-45 there will be low water again until 2055-56. According to the proposed regression equations between the average annual water discharge for a long-term period and their average values during the high-water and low-water phases of water content (with very significant approximation coefficients) and the obtained transition coefficients, it is possible to establish the calculated characteristics of the average annual flow of water of various availability in the high-water and low-water phases of water content, thereby giving their forecast estimates.

Keywords: average annual runoff, long-term variability, cycles and phases of water content, stochastic patterns, forecast estimates, the Pripyat river, rivers of the Pripyat basin within Ukraine.

Надійшла до редколегії 05.08.2021 